\title{
O PENSAR SONORO AUDIOVISUAL: A CONTRIBUIÇÃO DO SOUND DESIGN DE ALAN SPLET
}

\author{
Audiovisual sound thinking: the contribution of Alan Splet's sound design \\ Pensamiento de sonido audiovisual: la contribución del diseño de sonido de \\ Alan Splet
}

Fabiano Pereira de Souza Doutorando do PPGCOM, Universidade Anhembi Morumbi fabian59@gmail.com

Rogério Ferraraz

Docente do PPGCOM, Universidade Anhembi Morumbi rogerioferraraz@uol.com.br

\section{Resumo}

Editor de som de cinema e professor de graduação e pós-graduação da ECA-USP, Eduardo Santos Mendes aborda nesta entrevista o pensamento sonoro no audiovisual através do cinema. Ele resgata parte da sua trajetória como realizador e docente, para então chegar ao conceito do sound design, tema da disciplina que costuma lecionar para mestrandos e doutorandos. Para tanto, ele destaca os trabalhos de dois profissionais notáveis dessa função na produção de filmes, os americanos Walter Murch e Alan Splet, pelos aspectos de inovação em termos da narrativa e similitude na construção de relações audiovisuais.

Palavras-chave: Cinema. Sound design. Alan Splet.

\section{Abstract}

Film sound editor and undergraduate and postgraduate professor at ECA-USP, Eduardo Santos Mendes discusses audiovisual sound thinking through cinema in this interview. He remembers part of his career as an editor and professor, and then reaches the concept of sound design, the subject of the discipline he usually teaches for master's and doctoral students. To this end, he highlights the work of two notable professionals in this function in film production, the Americans Walter Murch and Alan Splet, by the aspects of innovation in terms of narrative and similitude in building audiovisual relations.

Key words: Cinema. Sound design. Alan Splet.

\section{Resumen}

Eduardo Santos Mendes, editor de sonido cinematográfico y profesor de pregrado y posgrado en ECA-USP, analiza el pensamiento de sonido audiovisual del cine en esta entrevista. Recuerda parte de su carrera como director y maestro, y luego llega hasta el concepto de diseño de sonido, el tema de la disciplina que generalmente enseña para estudiantes de maestría y doctorado. Con este fin, destaca el trabajo de dos notables profesionales en esta función de producción cinematográfica, los estadounidenses Walter Murch y Alan Splet, por 
los aspectos de la innovación en términos de narrativa y similitud en la construcción de relaciones audiovisuales.

Palabras clave: Cinema. Diseño de sonido. Alan Splet.

\section{ENTREVISTA COM EDUARDO SANTOS MENDES}

Editor de som de cinema e professor da Escola de Comunicação e Artes da Universidade de São Paulo (ECA-USP), Mendes tem ao longo de anos ministrado a disciplina Sound Design/Projeto de Som $^{1}$ - A Construção da Trilha Sonora no Cinema Narrativo Ficcional na pós-graduação, e outras ligadas a som na graduação. Toda sua carreira de docência, iniciada em 1990, prioriza a sensibilização e a reflexão do pensar sonoro nas obras audiovisuais. Seu primeiro crédito artístico de trabalho com som de cinema na lista do site IMDb, hoje com 41 créditos, é $O$ bandido da sétima luz (Brasil, 1987), de Paulo Caldas. Trabalhou na edição de som ainda em Kuarup (Brasil, 1989), de Ruy Guerra, Dois Córregos Verdades submersas no tempo (Brasil, 1999), de Carlos Reichenbach, e Tônica dominante (Brasil, 2000), de Lina Chamie. Já como sound designer, Mendes atuou em Antônia: o filme (Brasil, 2006), de Tata Amaral, Falsa loura (Brasil, 2007), de Reichenbach, e No meu lugar (Brasil/Portugal, 2009), de Eduardo Valente. Venceu o Troféu Calunga de melhor som do Cine PE - Festival do Audiovisual de 2004 por Contra todos (Brasil, 2004), de Roberto Moreira.

Em 2009, no XIII Encontro Internacional da Sociedade Brasileira de Estudos de Cinema e Audiovisual (Socine), realizado na ECA/USP, Mendes apresentou sua pesquisa Alan Splet: revisão crítica da obra, em que traçava aspectos estruturais do trabalho do sound designer americano, e recomendava uma pesquisa mais aprofundada sobre ele, muito lembrado por seus trabalhos para o cineasta David Lynch. Era um estudo complementar ao da sua tese, Walter Murch: a revolução da trilha sonora cinematográfica, sobre o também sound designer que, em trabalhos para Francis Ford Coppola, legou obras de sofisticadas relações entre sons e imagens, como Apocalypse Now (EUA, 1979), O poderoso chefão (The Godfather, EUA, 1972) e O poderoso chefão II (The Godfather: Part II, EUA, 1974).

\footnotetext{
${ }^{1}$ Sound designer é uma função da produção cinematográfica que surge nos Estados Unidos nos anos 1970. Cabe a ele toda a complexidade de se criar a identidade sonora dos filmes e todas as implicações técnicas para tanto, aplicar também ao som a estética prevista pelo diretor e proporcionar durante a produção a comunicação clara entre este e os chefes das equipes de som direto, edição de som e mixagem, o que antes não era regra.
} 
Esta entrevista com Eduardo Santos Mendes foi realizada para a dissertação de mestrado Alan Splet: O Sound Design de Veludo Azul e a Polifonia de Efeitos Sonoros (2016), do autor Fabiano Pereira de Souza, orientada pelo autor Rogério Ferraraz, defendida no Programa de Pós-graduação em Comunicação da Universidade Anhembi Morumbi. Portanto, além do panorama acadêmico e artístico traçado por Mendes, é também destaque seu entendimento sobre a contribuição de Splet para o pensamento sonoro no audiovisual.

\section{O que você destaca na sua experiência, tanto acadêmica, quanto artística? Os trabalhos mais relevantes, mais expressivos.}

EM - Tenho um carinho especial pelo Um céu de estrelas (Brasil, 1996, de Tata Amaral), porque, afinal, é o primeiro [longa-metragem]. Na verdade, é o segundo, mas é o primeiro dos estereofônicos, é o primeiro em que eu estava envolvido desde o início. Nesse esquema de “vamos atrás na reunião de pré-produção, discussão de roteiro", essa coisa toda. É o primeiro em que eu trabalho com ele do roteiro à mixagem. Então tem uma relação carinhosa. Tem um monte de curtas no meio com que eu tenho uma relação super carinhosa, que são relações de aprendizado. The MASP movie (Brasil, 1986, de Hamilton Zini Jr.), o Kyrie ou o Início do caos (Brasil, 1998, de Débora Waldman), Noite final menos cinco minutos (Brasil, 1993, também de Waldman). Tem diversos curtas que me deram caminhos diferentes. Tem outros filmes que eu faço com o [diretor] Carlos Adriano, que aí são não-narrativos. São mais sensoriais que qualquer outra coisa, mas sempre dentro de limites bem racionais [risos]. A gente abre um jogo, determina um jogo com regras muito claras e a partir daí vale qualquer negócio. São muito gostosos de fazer, gosto muito do resultado deles também. Gosto muito do meu trabalho no $O$ corpo (Brasil, 2007, de Rossana Foglia e Rubens Rewald). Na verdade, eu não posso reclamar muito da minha vida de editor porque nesses anos eu tenho trabalhado em filmes que me dão espaço de trabalho. Produções em que, quando as pessoas vêm me procurar, elas sabem que os filmes delas têm um espaço para um trabalho de som criativo, [outro] para um trabalho de som narrativo e assim por diante. Eu tenho uma coisa de não conseguir fazer trabalho mal feito. Então, [mesmo] para pagar aluguel, ele tem que estar fechadinho, bem armado, tem que ter uma coerência dentro dele, tem que ter uma lógica interna. Eu faço com o mesmo carinho Cinderela baiana (Brasil, 1998, de Conrado Sanchez) ou A casa de Alice (Brasil, 2007, de Chico Teixeira). 


\section{Você fez Cinderela baiana?}

EM - Eu fiz. Claro (risos). Aliás eu me diverti muito, eu e (o editor de som) Luiz Adelmo [Manzano] editamos juntos. A gente se divertiu muito fazendo Cinderela baiana. Você sempre acha alguma coisa bacana para se pegar e brincar sobre ela. É que tem alguns filmes que na concepção original deles, quer na escrita do roteiro, quer na mise-en-scène, não pensam o som como estrutura dramática. Mesmo. Não é pensado. E normalmente para esses filmes obviamente eles não te chamam no roteiro, chamam quando [o filme já] está montado. E aí, quando realmente você pega esses filmes que estão montados, não tem nenhuma articulação sobre a qual você possa trabalhar, o que você faz é uma perfumaria bacana. Você deixa o filme bonitinho, mais leve ou mais pesado. Vamos ao gosto do diretor. Não tem esse problema. E aí você vai brincando pelo caminho, você cria brincadeiras para você mesmo, por uma forma de seguir o negócio. Depois de um certo tempo que eu fiz "Cinderelas baianas" e "Casas de Alice", as pessoas começaram a me chamar para fazer mais "Casas de Alice". Porque elas perceberam que eu tinha um outro domínio de linguagem que me permitia extrapolar suas próprias ideias. São filmes que chegam para mim no roteiro, em que eu sento com as pessoas, a gente discute, prevê a própria técnica de captação, como vai ser feita, qual é a ideia mais lógica, como vai soar no final. Faz toda a discussão do som quando está fazendo a discussão da arte, da foto. Está todo mundo junto na mesma discussão. São pessoas que têm uma coisa diferenciada, que é quando você quer usar o universo sonoro a seu favor. São filmes que têm menos diálogos que a maioria. Porque quando você tem diálogo, não tem jeito. A sua percepção vai para o plano do diálogo imediato, dá uma travada no resto do plano sonoro do filme. E diálogo é uma relação racional, que depende do conhecimento da palavra, da língua, $100 \%$ racional. E a relação com o som não funciona por aí, com o som que não é a palavra dita. Então quando você tem filmes que operam muito no diálogo, você realmente não tem muito espaço para a criação. Você pode fazer o que eu chamo de perfumarias. Pegar uma sequência, o próprio ritmo da sequência para usar recursos com que você possa intervir sobre ela. Então, se é uma sequência de tensão, eu vou aumentar a quantidade de sons que quebrem para grave, médios para graves, ou se tem algum tipo de intensidade de presença, intensa, discreta, mas intensa, que sejam rítmicos, que sejam constantes. Eu vou gerar uma forma de intensificar o nervoso da situação. Mas vai sempre agir quase como música. É que música age sempre mais fácil. Ela já tem um código, que é super pré-estabelecido para a gente, ela funciona mais rápido. O resto dos efeitos sonoros até trazem uma carga de informação, 
conforme o efeito. Se uma porta é uma porta, um carro é um carro. Se você distorce um pouco essa porta, não sei mais se ela é uma porta. Então é um código muito mais difícil que você tem que armar na frente do seu espectador para ele entender aquele código. Música está codificada, então é fácil. Você já entende o código e você só tem que trabalhar sobre ele agora. Então quando você pega um filme em que o texto tem muito espaço, a voz tem muito espaço, o máximo que você pode fazer é usar o ambiente para ajudar na intenção da cena. E aí você vai trabalhando sobre isso. Você pode diminuir o tempo dos diálogos usando o som entre eles. Tem algumas pequenas técnicas que você faz, você acelera ou retarda o tempo de leitura de uma cena. E esse é um poder de som que mesmo um diretor que trabalha muito com diálogo, quando pela primeira vez ele faz um filme, ele leva um susto. O filme está fechado quando chega na sua mão, então você não vai impor ritmo, não vai mudar tamanho de imagem, fazer nada. Você vai trabalhar sobre aquilo que está feito.

\section{E com relação à parte acadêmica, quais você considera suas experiências mais interessantes?}

EM - Tentar botar na cabeça de uma nova geração que som é pensável. Que som tem que ter espaço no set. Que a escolha de um microfone vai implicar na escolha da forma de leitura dessa imagem. É isso que eu quero só. Despertar curiosidade, a sensibilidade para uma outra forma de percepção, para a qual a gente não é desperto no dia-a-dia. A gente é muito bem treinado para aprender a ver. Isso a gente faz direito. A sociedade ocidental é visual. E o cinema é chamado de a grande arte visual. Se a imagem está contando uma história, eu não preciso de mais nada. Ou seja, eu não preciso de diálogo, eu não preciso de música. É verdade. Cinema silencioso. A imagem está lá, eu consigo contar uma história, muito bem contada, fazer filmes de altíssimo nível, com grande discurso, sem som. Temos anos e anos de história, décadas de história de produtos belíssimos que se mantêm vivos até hoje. Então é um fato. Agora, se entra som na história, tem que combinar, senão a articulação fica desinteressante. Eu não preciso dele, literalmente. Mas se escolher usar, pensa. Então acho que a melhor coisa que eu fiz na ECA [USP] é tentar criar gerações que começassem a pensar som como diretores, roteiristas e produtores. Começassem a pensar em estruturas sonoras, pensar som como elemento a mais do filme. Tentar criar diretores, fotógrafos, produtores de set, assistentes de direção que saibam o que o responsável pelo som está fazendo no set e quais são as necessidades dele, para poder criar espaço de trabalho para ele. Que é uma coisa que acontece no mundo inteiro. Você começa a andar pelo mundo e a conhecer profissionais 
chiques, técnicos de som, franceses cheios de [prêmio] Cesar, técnicos americanos cheios de Oscar, reclamando da mesma coisa: não tem espaço de trabalho no set. Então, eu acho que o meu principal trabalho na ECA é ver se a gente consegue mudar um pouquinho do padrão. Estamos conseguindo. Acho uma graça ver os longas dos meus alunos chegando às telas. E aí você vê estruturas mais sofisticadas.

\section{De que eventos acadêmicos que você participa?}

EM - Basicamente, o grande evento acadêmico da área de que eu participo é a Socine ${ }^{2}$. Eu comecei a participar da Socine muito discretamente, aí a gente descobriu que tinha várias pessoas que discutiam a mesma coisa, começamos a nos encontrar. Um ia ver [a apresentação do] outro até a hora que a gente falou "por que a gente não se junta e tenta criar uma coisa um pouco mais sólida?". E, também, fazer com que o que a gente está tentando nos filmes e na escola se reflita ali também, que a academia comece a pensar som. Porque isso é um outro fato: não é só a realização que não pensa som, a academia também não pensa som. Eu já participei de bancas com acadêmicos renomados brasileiros que chegaram para mim e literalmente falaram "eu não entendo nada de som". Acadêmicos de cinema. Que admitem “não entendo; para quê?”. Eles discutem a imagem. Só que aquela imagem naquele filme não é muda. Alguém lhe dá um valor, de verossimilhança, ou de não-verossimilhança, ou de delírio etc. Existe um outro elemento que dá valor àquilo. E aquela imagem só existe naquele momento associada a esse valor sonoro. Então, não adianta você ficar dissecando aquela imagem feito um doido, a não ser que você seja um professor de fotografia e aí você está dissecando a entrada da luz, a composição do quadro, o que é uma outra história: estou trabalhando sobre uma imagem mesmo, de composição, uma outra leitura. Agora, usar aquela imagem como a forma narrativa, para fazer toda uma análise narrativa sobre aquela imagem, jogando fora o elemento sonoro que a acompanha eu não consigo entender. A gente foi se encontrando pelo caminho. Eu, Fernando (Morais da Costa, da UFF), Suzana (Reck Miranda, da UFSCar), Rodrigo (Octávio D’Azevedo Carreiro, da UFPE) um pouquinho depois. Então o nível da discussão já parte de uns três degraus acima. Já tem gente estudando performance, já tem gente estudando um monte de outras ramificações que os estudos do som permitem e ampliando a discussão.

\footnotetext{
${ }^{2}$ Mendes, ao lado de Fernando Morais da Costa (UFF) e Suzana Reck de Miranda (UFSCar), propôs e coordenou o primeiro seminário específico de estudos de som do evento, em 2009.
} 


\section{Como foi a descoberta do [trabalho do] Murch?}

EM - Vendo filme. Quando eu vi Apocalypse Now (EUA, 1979, de Francis Ford Coppola), falei: “OK, temos articulações aí muito complexas que podem ser feitas”. Dentro de narrativas ficcionais clássicas. Dá para eu fazer na narrativa clássica.

\section{Você já estava formado?}

EM - Não, eu era aluno da ECA. Mas não pensava em som assim tão intensivamente. [Depois] Hamilton Zini Jr. me chamou para fazer o som de um desenho animado, que eu achei o máximo. Desenho animado vale qualquer coisa. Aí um outro me chamou para fazer som não sei de onde e, de repente, eu estava editando som e estava fazendo som direto e achei tudo de bom porque tinha espaço para trabalho, tinha espaço de criatividade, de realmente pensar, poder desenvolver ideias etc. E não tinha ninguém querendo puxar meu tapete porque não tinha ninguém concorrendo comigo. Não precisava brigar com ninguém, era só estar na minha paz, no meu trabalho e fazê-lo. Não teve saída, eu tive que seguir nesse mundo. Um amigo meu que tinha ido para Berkeley fazer lá o film scoring, curso de música para cinema, trouxe o clássico da literatura [da área], que é aquele Film Sound - Theory and Practice, da Elizabeth Weiss. Depois que eu comecei a fazer som e descobri o livro, despertou o lado acadêmico, de organização acadêmica. Porque na ECA você não tinha nada, nenhuma referência de som, contexto. Tinha o [professor] Ismail [Xavier] que dava um texto clássico da Mary Anne Doanne, que é aquele sobre voz no documentário, mas parava mais ou menos por aí. E [tem] uma coisa que eu sempre fiz no começo da carreira - e, de vez em quando, faço até hoje: se eu pego um filme para fazer e não tenho referências, vou ver o que os outros tinham feito. Você pega boas ideias. Coisas que você precisa resolver de mudanças de plano já estão bem resolvidas. Tem coisas de que você acha a ideia boa, mas você pode melhorar. E aí você vai criando um repertório criativo. Eu gosto muito do cinema americano dos anos 70, acho uma turma super criativa, viva, engajada, você vê que eles estão fazendo com garra os filmes deles, uma coisa de cinema. Acreditam no que estão fazendo, não é um discurso comercial, é um discurso ideológico. Comecei a rever essas obras e fui atrás do pessoal da 
Director's Company, que é a pequena produtora que o Coppola criou lá no comecinho [de sua carreira]. ${ }^{3}$

\section{Murch já fazia parte?}

EM - Murch fazia a parte de som, mas o Coppola juntou vários diretores para fazer a "Nouvelle Vague americana". Essa era a ideia básica. Ele estava com um contrato com Hollywood que lhe permitia produzir filmes dos outros. Porque, para o Coppola fazer o $[O$ Poderoso] Chefão II, ele fez um contrato com que Hollywood ia ter que produzir um filme que ele quisesse, que ele fosse dirigir e que não tivesse interferência do estúdio, que foi $A$ conversação (The Conversation, EUA, 1974), e ainda fazer não sei quantos filmes para os outros [como produtor]. E é por isso que ele produziu um filme para o [diretor] Carroll Ballard, ele produziu um filme para o [diretor e produtor] George Lucas, ele saiu fazendo essas pequenas produções.

\section{Para Ballard qual foi o filme?}

EM - O corcel negro (The Black Stallion, EUA, 1979). E aí, [foi] via Coppola, via Carroll Ballard, que eu cheguei no Splet. Quando eu voltei para a pós-graduação, eu já tinha toda essa visão muito mais armada. Já tinha lido, visto como funciona gênero, descoberto que tinha autores que pensavam som de forma autoral literalmente. Tem um pensamento realizado que não compromete o filme, mas que se mantém presente. Tudo isso estava organizado muito claro na minha cabeça quando eu voltei para a pós. Então, acho que eu ganhei, na verdade, esse tipo de conhecimento enquanto eu estava no mercado, correndo atrás dos meus filmes. Precisava correr atrás da informação. Desde física, de voltar a estudar eletricidade, coisas que eu não tive no colegial, porque eu estudei em escola pública durante a decadência do ensino público. Não tive professor, não tinha curso. A grande vantagem é que a minha escola ficava na frente do [Cine] Bijou, na Praça Roosevelt [em São Paulo, capital]. Então, quando não tinha duas aulas seguidas, eu via o que tivesse em cartaz. Vi O encurralado (Duel, EUA, 1971, de Steven Spielberg), um monte de [filme de] Buñuel...

\footnotetext{
${ }^{3}$ A Director's Company foi criada por Francis Ford Coppola, Peter Bogdanovich e William Friedkin no início dos anos 1970 .
} 


\section{9. [Então, a partir] de Murch, que primeiro chamou sua atenção, você chegou aos [sound designers] contemporâneos Ben Burtt e Splet. E o que você considera a maior relevância do trabalho de Splet?}

EM - Tem um cinema que hoje começa a voltar à moda cada vez mais. Você tem muitos tipos de cinema, mas um tipo de cinema que está muito na moda e eu gosto bastante é um cinema que brinca com uma certa verossimilhança, um certo realismo, que de realismo está longe de ser. E que tem muito do peso da sua carga no som. De leitura, de todo o sentido daquilo dentro do som. E é esse tipo de cinema que me atrai muito, que é um cinema muito mais sensorial que narrativo. Ele está muito mais a fim de te captar com sensações. Tem uma história sendo contada, tem um desenvolvimento, existem personagens, eles vão se transformar no final. Todos os códigos estão lá, de uma narrativa clássica, está tudo acontecendo. Aristotelicamente falando, a narrativa com percurso do personagem está lá. Mas a forma que se conta isso, a forma que se chega a essa narração não é pela narração e sim pela interioridade dos personagens. Pelo seu interior, pelo seu sentir e é quase mais uma vez um impressionismo, de alguma forma. Que é o cinema da [cineasta argentina] Lucrecia Martel, por exemplo. Ele é narrativo, existe uma historinha, a mulher vai lá, atropela alguma coisa, que não sabe se é uma criança ou não, mas [ela] bota na cabeça dela que é uma criança e foge, e aí começa a entrar em conflito etc. Mas interessa menos a história que está sendo contada e sim a nossa percepção do mundo daquele personagem. A forma que a gente percebe aquela personagem e que o mundo dela nos é apresentado. E é esse tipo de cinema que me encanta. Eu estou abrindo aquela imagem para um monte de caminhos, onde você pode se guiar por ela por onde a sua emoção se sensibilizar com aquela história, aquela imagem, aquela relação audiovisual. Esse poder que o cinema tem de ser literalmente sensorial - você sai com sensações, claras, físicas - me deixa absolutamente encantado. E nisso Splet é o aperfeiçoamento de Murch (risos), digamos assim. É que Murch também trabalha na mesma linha. Apocalypse é um festival disso, de sensorialidade, mas ele se prende o tempo todo à verossimilhança. E quando ele delira, ele faz uns delírios lindos, maravilhosos, [mas] no final ele justifica. Ele tem que justificar de alguma forma, ele tem que deixar aquilo verossimilhante de alguma forma. E o Splet não. 


\section{Isso é Splet ou Lynch?}

EM - São os dois. Tanto que quando você pega o trabalho dos dois em separado eles continuam fazendo a mesma coisa. E quando os dois se juntam, aí você junta a fome com a vontade de comer. Você tem o sujeito que articula o cinema inteiro dele assim com o sujeito que pensa som como o outro pensa o cinema dele. Dois criadores que criam muito bem e sobem a bola um do outro. Agora, se você pega o cinema do Splet fora do Lynch... É claro que como eu, como o mundo inteiro, a gente tem que fazer "Cinderelas baianas" para sobreviver. Faz parte da nossa sobrevivência. Então a gente vai fazer filminho de passarinho e cachorrinho. Mas, no meio desse caminho, cai no colo dele coisas como O corcel negro, Os lobos nunca choram (Never Cry Wolf, EUA, 1983, de Carroll Ballard)... E aí o fino do filme, montado pelo Murch com som do Splet: A insustentável leveza do ser (The Unbearable Lightness of Being, EUA, 1988, de Philip Kaufman). Aí você vê que, quando ele tem espaço de criação, como com $O$ corcel negro, ele segue a mesma linha que usa nos filmes do Lynch. É sensorial. Ele está a fim de causar sensações. E para isso não lhe interessa muito verossimilhança. Para isso, ele vai pegar uma cobra e transformar num monstrinho. Ter vida, ter presença, ser malvada, que nem desenho animado, sem problema nenhum. Ele vai desestruturar o ambiente: o mesmo lugar no mesmo tempo pode ter dois sons diferentes. $\mathrm{O}$ que interessa é essa sensorialidade, esse outro olhar sobre a imagem, esse outro olhar sobre a lógica narrativa. Então, isso no Splet, é muito claro nos filmes do Carroll Ballard, claríssimo. Isso existe no [filme do] Kaufman. Quando ele tem espaço de trabalho com pessoas que pensam como ele, que tem esse outro tipo de narrativa, está lá claramente o cinema que ele faz. E quando você pega os filmes do Lynch sem o Splet, está lá também a forma como o Lynch articula os seus filmes, a relação da imagem e som, da mesma forma. [Quando] você começa a ver os curtas do Lynch antes de The Grandmother (EUA, 1970), ${ }^{4}$ [é possível perceber que] ele é um artista plástico, que pensa bem a imagem. Uma criação imagética boa, ele é assumidamente um expressionista... Ele tem essa imagem bacana, articula muito bem, começa a entender cinema, está pensando o cinema como artista plástico, mas você vê que ele começa a articular linguagem, como funciona, está tentando entender essa outra linguagem. Mas o pensamento sonoro é bem inferior ao que ele vai desenvolver depois. Aí, quando vem

\footnotetext{
${ }^{4}$ Primeiro filme em que Lynch e Splet trabalharam juntos.
} 
The Grandmother, ele dá um salto na estrutura audiovisual, que depois fica redonda em Eraserhead (EUA, 1977). ${ }^{5}$ E aí a coisa só se desenvolve.

\section{O que caracteriza o trabalho do Splet? As características mais marcantes que você} observa.

EM - A forma como ele trabalha com ambiente, que ele faz do ambiente um pulso vivo, um personagem. Você pode usar o ambiente para dar tridimensionalidade à imagem, é a função básica dele. Mas ele usa ambiente para contar história. A função do ambiente dele é narrativa, não para gerar verossimilhança. Mesmo dentro do verossimilhante, ele usa dessa mesma forma. Isso eu acho uma característica muito forte, muito bonita. Eu gosto da forma com que ele faz objetos ou mesmo seres inanimados criarem personalidade. Passam a ser personagens, seres vivos, com raiva, com ódio, com violência... E acima de tudo, a liberdade com que ele trata sons, pensando muito mais no caráter sonoro daquilo, do que ele consegue tirar como pulso, como timbre, como sonoridade propriamente dita, do que da sua verossimilhança. Então, essa liberdade de pegar um som de um outro universo e trazer para um universo onde você nunca o juntaria, mas que para a relação audiovisual tem o efeito perfeito que se queria. Como o bendito trem no $O$ corcel negro, o cavalo que vira uma locomotiva, literalmente uma locomotiva. É sempre pensar articulado com a narrativa do filme. Você [enquanto sound designer] não está querendo brilhar mais que o filme, você é mais um elemento dentro daquilo. E pensar toda a trilha sonora do filme como uma grande partitura de duas horas, que tem que ter dinâmica no meio, tem que ter respiros, que tem que ter elementos sonoros, sejam eles musicais, vozes ou efeitos sonoros como um jogo, articulados como um todo, dentro de um único fluxo de leitura. Acho que isso ele articula extremamente bem.

12. Por exemplo, o vento, [elemento] que ele trabalha muito. Pensando mais em Lynch, tem momentos de ventos que não estão na cena [como em Eraserhead]. Não está ventando naquele quarto e você está ouvindo aquele vento claramente. Não é lá fora, é uma coisa interna.

EM - A chave está aí. A chave do outro discurso que eu disse antes. O som não é externo, aliás, o som não é da imagem, o som interno é uma personagem ou uma sensação impressionista mesmo.

\footnotetext{
${ }^{5}$ Primeiro longa-metragem dirigido por David Lynch e segunda parceria entre ele e Splet.
} 
13. Tem essa sobreposição de efeitos sonoros extra-diegéticos perceptíveis em cena, inclusive para um leigo. A gente sabe que, em edição de som, é muito comum usar coisas que não foram gravadas na cena, mas a maior parte do tempo o ouvido leigo "lê" como verossimilhante.

EM - O Murch faz isso de uma forma em que você não percebe a não-verossimilhança. O Splet já muda conforme a cena, a necessidade da cena. Se a cena tem um caráter mais verossimilhante, ele continua explodindo o balde lá atrás fazendo de conta que aquilo é de verdade. Um vento dentro de um quarto com a janela fechada, mas tudo bem, você aceita.

14. [Ele usa] vozes distorcidas ou trocadas por efeitos sonoros em alguns momentos com o Lynch. Troca a voz por outra coisa ou distorce a voz de forma que ela é outro efeito sonoro.

EM - É que a voz deixa de ter uma característica semântica e você trabalha só com a questão de timbre, de emissão, como qualquer outro efeito sonoro, só que é humano.

\section{Algum outro espaço de trabalho criativo para ele?}

EM - Ballard se interessa muito mais pela personagem do que pela história. Você tem grandes espaços de trabalho. E ele também tem desse mesmo tipo, o de trazer essa sensorialidade para dentro. Tanto $O$ corcel negro quanto o Os lobos nunca choram. Então, a primeira metade inteira de $O$ corcel negro é um menino sozinho numa ilha. Ele não abre a boca. Como tem muitas sequências que são relativamente semelhantes, ele também tem essa sensibilidade de [decidir que] "essa sequência é para música". Quanto mais a música tiver seu espaço, melhor. Agora, acabou a sequência de música, [vem] sequência de não-música. E assim vai criando também um equilíbrio de respiros, de novas sensibilidades, fica bem bacana. E não dá uma crueza, que é a ausência de música para o espectador normal de cinema. É uma coisa pesada um filme sem música. E Os lobos nunca choram é a história de um cara no Ártico, sozinho. São filmes bonitos, bem filmados. Se puder ver em tela grande, melhor. 
16. Temos a sobreposição dos efeitos sonoros extra-diegéticos, contraste entre imagens e sons em alguns momentos, a voz sendo distorcida ou trocada por efeitos sonoros em personagens sem deformação física - [diferente daquilo] que é comum no cinema de horror. Por exemplo, em $O$ exorcista (The Exorcist, EUA, 1973), de William Friedkin. A voz muda quando há uma deformação física. Com Lynch e Splet, a personagem tem a mesmíssima condição física com apenas a voz sendo distorcida num efeito de estranhamento, não um efeito de criação clara de sentido. Uma coisa para te desacomodar na noção de sentidos. Considerando essas características, quem depois do Splet de alguma forma adotou essas práticas?

EM - Não posso dar nomes, não tenho de pronto assim. Mas o que acontece no cinema hoje, já faz um certo tempo, principalmente pós-Splet, pós-Murch, é que você não precisa mais justificar nada para ter um outro caráter de verossimilhança. Antes, para eu poder fazer com que um som tivesse um caráter mais sensorial, eu teria que fazer com que a personagem estivesse bêbada ou com sono... Eu tenho que mudar a percepção dessa personagem, tenho que ajustar essa percepção natural e, a partir dessa mudança de estado, eu posso também fazer uma mudança do estado do som e aí eu tenho a liberdade que eu quiser, afinal ela está bêbada. Eu tenho que ter alguma coisa que me permita, que me justifique esse tipo de percepção. $\mathrm{O}$ cinema contemporâneo, até blockbuster americano, sem (o personagem) precisar estar bêbado, já deforma completamente a estrutura de som para a criação de efeito. Pode ser efeito de qualquer outra coisa, efeito de super-herói, não interessa. Mas essa ideia [clássica de] que o som tem que acompanhar $100 \%$ de verossimilhança daquela imagem não é mais válida. O cinema que você tem hoje pulsa entre verossimilhante e não verossimilhante, entre naturalismo e não naturalismo. Ele se modifica a cada cinco minutos. Num filme rotineiro, você já tem pausas de repousos ou de respiros, ou sejam lá do que for, que permitem uma nova trilha sonora diferente daquela trilha sonora tradicional verossimilhante. Essa ideia de você usar o som como a introspecção do personagem e tentar fazer a representação desse mundo interior através dele, você tem isso em blockbuster. Em "Batmans" da vida. Então, eu acho que essa liberdade com que esse pessoal dos anos 70 bate forte, já foi assimilada pelo grande cinema. Pelo cinemão, pelo cineminha, pelo cinema de autor, todo mundo. Ninguém mais tem medo de pegar uma sequência e dar uma modificada no fundo dela para coisas que não sejam absolutamente verossimilhantes. Nem que seja por cinco minutos, três minutos. Filme hoje já faz isso o tempo todo sem justificar uma alteração no estado de percepção. Eu 
acho que esse caminho, que aquele pessoal começou a trilhar, está hoje em tudo que é canto, por todos os lados.

17. O que a gente poderia talvez notar de diferença entre Splet e Much e o que se faz atualmente é aquele chamado hiper-realismo, [já] que hoje o cinema tem uma enxurrada de efeitos sonoros, especialmente o cinema de ação, talvez por uma questão de distribuição do som na sala para tornar o espetáculo mais envolvente, surpreendente. Mas é um excesso de informação sonora confluindo para uma mesma situação. Está certo? Para uma imersão maior no que a imagem está mostrando, mas não te tira da compreensão da cena, não te desacomoda daquela situação.

EM - Não, não é errado. É que, na verdade, o que se chama de hiper-realismo hoje é esse aumento de volume em cada som. Volume, literalmente. Não quantidade de informação. Mas isso está sendo usado na maioria das vezes numa condição de representação sensorial mesmo, tentando chegar aos personagens sensorialmente.

18. Uma camada sensorial cada vez mais rica para te envolver, mas talvez nesse sentido que a gente estava falando, um envolvimento para dentro do que está se mostrando na cena. Não te tira [da narrativa], não te faz divagar.

EM - Ah, não. Não é feito para romper.

19. O que talvez o trabalho do Splet, pelo menos em alguns momentos, faz é que você está ouvindo para fora. Você separa e fica no estranhamento.

EM - Mas esse estranhamento tem uma função narrativa muito clara naquele momento. Ele quer que você estranhe a reação daquele personagem. Quando ele bota o cara da mascarazinha [Frank Booth, personagem de Dennis Hopper em Veludo azul (Blue Velvet, EUA, 1986, de David Lynch)] berrando como um leão - não lembro mais o tom [que era], completamente deformado, com uma respiração simultânea - ele quer o seu estranhamento.

20. Sim, mas o que se faz hoje não é para o estranhamento. É para uma imersão.

EM - Entendi. Mas o estranhamento não te tira da imersão. O que tem de diferente entre uma coisa e outra não é imersão ou não imersão, porque quando eu estou vendo Veludo azul e aparece aquele negócio eu não saio do filme. Não é como um filme do [Jean-Luc] Godard ou 
do [Rainer Werner] Fassbinder, em que ele me corta o áudio total, eu levo um susto e saio da narrativa, saio da história do filme. Porque é feito para eu cair fora, para eu voltar a assumir uma posição racional. Eu acho que nenhum dos dois tipos de cinema está propondo isso. Seja o tipo de cinema do Lynch, seja o tipo de cinema do Christopher Nolan, ${ }^{6}$ que usa muito esse recurso, mas para fazer um outro cinema. Eu acho que o que muda é uma questão de você criar algum tipo de agressividade, algum tipo de rejeição do seu espectador. Rejeição, mas sem perder a ligação emocional, que é a essência do cinema americano. Não se quer que você em momento nenhum racionalize que aquilo é um filme. Você tem que ficar emocionalmente ligado àquilo durante a projeção. Desse princípio básico não foge. E quando você me fala de rejeição me dá essa impressão de Godard, Fassbinder, que não querem o seu envolvimento emocional. Eles querem um afastamento brechtiano em alguns filmes. Então, o que você tem no caso do Lynch e do Splet juntos é uma sensação de repulsa, sensação de asco, sensação desagradável. Mas você continua ligado àquilo, até porque se alimenta essa sensação que continua dentro do filme.

\section{Você não acha talvez que essa rejeição de que falou, esse asco ou incômodo, é porque ele te desacomoda do que seria a verossimilhança?}

EM - Não, acho que ele te desacomoda do que seria agradável, do que seria fácil. Pode se dar pela não-verossimilhança, mas é uma não-verossimilhança agressiva. É diferente de um filme do Batman, que tem a mesma não-verossimilhança, a mesma ideia, o mesmo recurso, com a mesma técnica etc, mas não te agride. Pelo contrário, quer te envolver mais. Então, eu não sei se é a não-verossimilhança que causa a agressão. É que rejeição dá essa sensação de afastamento, quando eu rejeito eu me afasto. Eu não estou me afastando, eu só estou tendo uma sensação ruim. O Lynch se permite a sensação ruim. Faz parte. O cinema americano clássico não pode ter sensações ruins. A não ser que você resolva daqui a dois minutos. Aí pode. Se você passa mal e depois resolve, tudo bem. Porque você não quer o afastamento afetivo do espectador.

\footnotetext{
${ }^{6}$ Christopher Nolan dirigiu três longas do personagem Batman, entre outros filmes.
} 
22. Em vez de te afastar, como fazem o Godard e o Fassbinder, ele te faz mergulhar ainda mais no incômodo desses personagens. Ele não te tira da percepção da experiência, ele te faz entrar no pesadelo por essas chaves.

EM - Sim, ele quer você dentro. Por chaves sensoriais, não racionais. Ele trabalha com elementos sonoros que te causam sensações, claramente. O sensorial é mais importante que o racional, é mais importante que o verossimilhante. E é tão narrativo quanto ou talvez mais narrativo. No sentido de "estou contando uma história, afinal". Não posso nunca perder esse foco, um foco importante, o foco de storytelling. É trazer esse estranhamento para o primeiro plano. Que é uma coisa que, em Lynch, ele [Splet] pode, que no Carroll Ballard ele pode, mas em alguns filmes ele não pode, aí ele tem que trabalhar por trás. Porque o filme é verossimilhante demais, não faz parte do filme trabalhar com o surrealismo, exacerbar, distorcer. Então a distorção até entra, mas pelo ambiente [sonoro]. Em vez de trazer o passarinho, o passarinho que ele traz é uma gralha e essa gralha está distorcida. Ou uma araponga, só que essa araponga está distorcida. A araponga já é distorcida naturalmente. Aí você trabalha a araponga para ficar mais esquisita. Ela é um elemento verossimilhante, naquele lugar podia ter uma araponga. Aliás, $90 \%$ dos espectadores não vai ouvir a araponga, porque ela está em segundo plano em relação ao diálogo. Mas ele vai pegar essa araponga, distorcer essa araponga e criar um clima muito esquisito para essa araponga, para dar um jeito naquela cena que tem um diálogo muito estranho. Mas que é $100 \%$ verossimilhante. Acho que é por aí que o registro funciona. Você pega a situação da cena, o que é importante, o que está sendo contado e transforma numa sensação sonora. E aí você pega essa sensação sonora e joga no meio de um espaço verossimilhante. Acho que é um caminho em que ele anda.

\section{Os sons analógicos da época do Splet contribuíram para a produção e a audição daqueles efeitos? A parte técnica contribuía, limitava? Perdeu-se algo no sistema quando se fez a transição para o digital?}

EM - Uma coisa não necessariamente implica em outra. Qualquer bom criador sabe bem seu limite técnico e vai trabalhar bem dentro do seu limite técnico para tentar passar dele, vai ser sempre maior que ele. Isso é o bê-á-bá. A gente sabe até onde a gente pode ir, aí fica revoltado com isso e então vai querer ir um pouco além e pronto. É assim que as coisas funcionam, até no digital, seja onde for. Eu não acho limitante, tanto que ele fez o que fez. Se você pensar nos filmes mais simples, como Eraserhead ou The grandmother... Tudo bem, são 
filmes sem dinheiro. Cuja proposta estética também é outra. Claramente é um filme lowbudget (de baixo orçamento), que está trabalhado em função de ser low-budget, que não está a fim de trabalhar numa verossimilhança. Ele é um filme surrealista, desde sua apresentação se mostra como filme surrealista. Então é um filme que, por exemplo, tem muito menos quantidade de som do que esses longas-metragens que ele [Lynch] fez depois. Até porque é mono, não é estereofônico, não precisa de quatro, oito canais [de som], esse tipo de coisa. $\mathrm{Na}$ prática, para eles [Lynch e Splet], não acredito que o ser analógico é limitação. O que aconteceu depois com o digital, que é realmente uma mudança gigantesca para a gente que trabalha com som, é que eu passei a conseguir ouvir dois sons ao mesmo tempo enquanto eu estou trabalhando. E isso é uma mudança gigantesca. Porque quando a gente trabalha em analógico, você trabalha com duas cabeças de som, no máximo três. Mas era raríssimo encontrar moviolas de três cabeças, normalmente são duas cabeças de som. Então você ouve o filme de dois em dois. Para a criação de efeitos sonoros você pode até ter um gravador multipistas do seu lado, com que você vai criando efeito, até achar que o efeito está bacana e aí você transfere para o filme. Facilita a vida. Mas a gente aprendeu ao longo do tempo a ter memória auditiva. [Por exemplo,] quando prever o som já sabendo que aqui está entrando um grave, então o próximo tem que ir para o agudo, tem que ir para as médias, senão ele vai matar aquele. É que, hoje, ele [Splet] teria muito mais para brincar. A capacidade de brincadeiras ia ser mais fácil porque ele já começa ouvindo 120 canais simultâneos, se ele quer fazer uma distorção é só pegar um botãozinho e fazer assim. Não tem que fazer todo o esteio de cabo, que passa por uma maquininha...

\section{Não existe chance de ter havido alguma perda de qualidade ou de algo relevante [em termos de alterações] quando a gente assiste aos filmes dele em digital?}

EM - Não, tem um caminho contrário, mas no caso dele não. Ele [Splet] já entrou para o cinema de longa [com estrutura de estúdio] com Dolby Stereo. Filmes com quatro canais, esse tipo de coisa. Duna (Dune, EUA, 1984, dirigido por Lynch) é quatro canais, O homem elefante (The Elephant Man, EUA, 1980, dirigido por Lynch) é quatro canais... Só os filmes de baixo orçamento são mono. O que você tem muito hoje, e isso é um problema para a minha área como acadêmico, um problema seríssimo, como estudo, é que você não tem mais as mixagens originais monofônicas. Por exemplo, o som original de $O$ exorcista você não acha mais, do O poderoso chefão, do Guerra nas estrelas... Mesmo sendo a versão Dolby estéreo, 
você só acha a versão digitalizada. E os produtores aumentaram a quantidade de sons, e refizeram não sei o quê...

\section{Mais mãos em cima do que era o original.}

EM - Exatamente, revisto e ampliado. Aí você perde o filme, a concepção original do filme. Tanto que eu estou encantado que agora saiu o Blu-ray que traz a versão original de $O$ exorcista. Porque $O$ exorcista tem uma versão de lançamento e, alguns anos depois de o filme ser lançado e fazer sucesso, saiu um director's cut, e aí já era em Dolby estéreo, quatro canais etc. E depois relançaram esse director's cut numa remasterização digital, mais chique ainda. Então, conseguir O exorcista [original] de 1973, sem director's cut, mono, é quase impossível. Esse lançamento foi lindo, fiquei feliz de conseguir. O som monofônico é bom, som analógico é bom, é verdade. Você tem que trabalhar sobre as limitações.

\section{Para analisar o trabalho de uma época, tem que ser nos termos da época também.}

EM - Você tem que ler com os olhos que você tem. Isso é um problema. Quer dizer, para mim não é um problema. Para mim é fácil, mas é um problema para muita gente, querer que a coisa soe como soa hoje. Não, não soa. Soa aquilo. E essa sonoridade para aquela época é muito boa! Então, tecnicamente não. Não há limitações assim. O analógico e o digital não vão mudar nada na vida do homem. Talvez hoje, em que tudo virou plug-in, você não tem mais que ficar comprando um monte de hardware. Você não tem que pegar um gerador de frequência para gerar uma frequência pura e começar a partir dela e deslanchar o que você quiser. Sabe esse tipo de coisa? Talvez o Splet brincasse mais, só isso. Só ia dar menos trabalho. Mas, claramente, ele não tinha limitação pelo analógico.

\section{Para finalizar, Eduardo, e o contrário? Ao ouvirmos hoje um DVD, alguma coisa online de um filme dele, não vamos perder qualidade?}

EM - Quando começou a imagem digital - começaram as TVs digitais, TVs de plasma etc, e agora só existem essas coisas no mercado - fiquei bastante irritado com a qualidade da imagem. Aquela imagem me cansa. É bonita, é brilhante, tem definição, as cores são vivas, é uma coisa linda. E o som tem a mesma característica. Mas aí é uma questão estética. Com o analógico você conseguia menos, aliás não tem como não ter sujeira na imagem analógica. $\mathrm{O}$ analógico carrega consigo o ruído, ruído de imagem, ruído de som, nesse sentido da sujeira. 
[O digital] é apenas um código. Que daqui a 20 anos muda. Então código é sempre a época, o contexto. Essa discussão não existe, na minha opinião. Não é que não existe, não faz sentido. Você trabalha com a tecnologia que você tem na época, com a cultura que você tem na época, conceitos que você tem na época e isso vai gerar um código que vai se dizer verossimilhante, ou não-verossimilhante, ou isso ou aquilo.

Original recebido em: 20 de outubro de 2019

Aceito para publicação em: 1 de maio de 2020

\section{Fabiano Pereira de Souza}

Doutorando e Mestre do Programa de Pós-Graduação em Comunicação da Universidade Anhembi Morumbi/SP. Bolsista CAPES. Possui especialização em Cinema, Vídeo e Fotografia Criação em Multimeios (2008), graduação em Comunicação Social - Jornalismo (2002) e graduação em Design Digital (1997), todos pela Universidade Anhembi Morumbi. Integrante do grupo de pesquisa, inscrito no CNPq, Cinema expandido, da estereoscopia ao web footage: novos regimes de visualidade no século XXI.

\section{Rogério Ferraraz}

Professor do Programa de Pós-Graduação em Comunicação da Universidade Anhembi Morumbi/SP. Doutor em Comunicação e Semiótica pela Pontifícia Universidade Católica/SP. Atua nas áreas de Comunicação e Artes, com ênfase em Cinema e Televisão. Foi líder do Grupo de Pesquisa Formas e Imagens na Comunicação Contemporânea (CNPq), vice-líder do Grupo de Pesquisa Inovações e Rupturas na Ficção Televisiva Brasileira (CNPq), rede OBITEL. Na SOCINE, faz parte do Conselho Deliberativo (biênio 2019-2021).

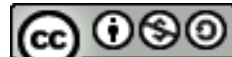

Esta obra está licenciada com uma Licença

Creative Commons Atribuição-NãoComercial-CompartilhaIgual 4.0 Internacional 